\title{
Cotton or Jute Dust Exposure
}

National Cancer Institute

\section{Source}

National Cancer Institute. Cotton or Jute Dust Exposure. NCI Thesaurus. Code C156872.

Environmental, occupational, or consumer-based exposure to airborne cotton or jute

fibers created during the manufacture, processing, or handling of these materials. 